\title{
Undergraduate Curriculum In Supply Chain Management
}

Kizhanatham V. Ramaswamy, (E-mail: Boyd_jl@tsu.edu), Texas Southern University Joseph L. Boyd, (E-mail: ramaswamy_kv@tsu.edu), Texas Southern University

\begin{abstract}
A proposal is presented for an undergraduate curriculum in Supply Chain Management(SCM) in a typical BBA program in an AACSB accredited Business School.
\end{abstract}

\section{INTRODUCTION}

$\mathscr{T}$ he motivation for this proposal stems from the need to develop future managers to manage business operations in a highly competitive global environment. It has been reported that every year more than $\$ 1500$ billion of materials are purchased by manufacturing firms and the expenditure for purchases of materials and services at federal, state and local governments is of the order of $\$ 1000$ billions[1]. According to Chopra and Meindl [2] a supply chain consists of all parties involved, directly or indirectly, in fulfilling a customer request for a product or service. Van der Zee and Van der Vorst [3] define supply chain management "as the integrated planning, coordination, and control of all logistic business processes and activities in the supply chain to deliver superior customer value at less cost to the supply chain as a whole while satisfying requirements of other stakeholders in the supply chain". Thus the supply chain includes not only the manufacturers and suppliers, but also transporters, warehouses, retailers, and customers themselves. The supply chain, in the context of large corporations, is global in scope. Service sectors like health care, department store chains, energy, and hospitality industry, for instance, have complex supply chains and require well trained people to manage them. Vakharia[4] gives the following perspective for supply chain management: "SCM is the art and science of creating and accentuating synergistic relationships among the trading partners in supply and distribution channels with the common shared objective of delivering products and services to the right customer, in the right quantity, and at the right time". According to Hausman [5] SCM is one of the leading edge strategies for business process reengineering, cost saving, and revenue enhancement today. SCM curriculum continues to be incorporated in business school programs in recent years at a fast pace. The next section presents the proposed SCM curriculum.

\section{SUPPLY CHANGE MANAGEMENT CURRICULUM}

The proposed curriculum is comprised of the following and leads to the BBA degree with a major in Supply Chain Management. The curriculum is based on existing and proposed new courses in the business school at Texas Southern University, Houston, TX.

\begin{tabular}{|c|l|}
\hline General education core curriculum & 44 Cr. Hrs. \\
\hline Other requirements & 22 Cr. Hrs. \\
\hline Business Core requirements & 30 Cr. Hrs. \\
\hline SCM Major requirements & 33 Cr. Hrs. \\
\hline Total & 129 Cr. Hrs. \\
\hline
\end{tabular}




\begin{tabular}{|l|l|l|c|}
\hline \multicolumn{2}{|c|}{ General Education Core } & \multicolumn{2}{c|}{ Other Requirements } \\
\hline (44 Credit Hours) & Cr. Hrs & (22 Credit Hours) & Cr. Hrs \\
\hline Freshmen English & 6 & Economics(200 level) & 3 \\
\hline Math (Freshmen Algebra) & 3 & Math( Freshmen Calculus) & 3 \\
\hline $\begin{array}{l}\text { Natural Science (Freshmen) } \\
\text { (Chemistry, Physics or Biology) }\end{array}$ & 8 & Basic Statistics (200 level) & 3 \\
\hline Speech Communication(Freshmen) & Sociology & 7 \\
\hline Sophomore English & 3 & Non-business electives & \\
\hline History (200 level) & 6 & & \\
\hline Political Science(200 level) & 6 & & \\
\hline Computer science ( Freshmen) & 3 & & \\
\hline Psychlogy (Freshmen) & 3 & & \\
\hline Fine arts & 3 & & \\
\hline
\end{tabular}

\begin{tabular}{|l|c|}
\hline \multicolumn{1}{|c|}{ Business Core } & Cr. Hrs. \\
\hline (30 Cr. Hrs.) & 6 \\
\hline Acctg 231 \& 232 (Principles I \& II) & 3 \\
\hline BADM 101 Introduction to Business \& Entrepreneurship & 3 \\
\hline BADM 230 Advanced Communications Skills & 3 \\
\hline BADM 234 Advanced Communication Skills & 3 \\
\hline FIN 301Basic Financial Management & 3 \\
\hline MGMT 300 Principles of Management & 3 \\
\hline MKTG 306 Principles of Marketing & 3 \\
\hline MGSC 302 Operations Management I & \\
\hline BADM 450 Organizational Policy and Strategy & 3 \\
\hline
\end{tabular}

All the courses listed above under General Education Core, Other Requirements and Business Core are currently being offered at the university. All students in the existing major areas in Finance, Management and Marketing are required to take these courses. The proposed SCM major includes existing and new courses (bold).

\begin{tabular}{|l|c|}
\hline \multicolumn{1}{|c|}{ Proposed Undergraduate Courses for Major in SCM } & Cr. Hrs. \\
\hline (33 Credit Hours) & 3 \\
\hline MGSC 331 Business Statistics (Existing) & 3 \\
\hline MGSC 303 Operations Management II (Existing & 3 \\
\hline MGSC 304 Information Technology (Existing) & $\mathbf{3}$ \\
\hline MGSC 307 Purchasing Management (New) & $\mathbf{3}$ \\
\hline MGSC 309 Logistics Management (New) & 3 \\
\hline MGMT 402 International Management (Existing) & 3 \\
\hline MKTG 430 Marketing Research (Existing) & $\mathbf{3}$ \\
\hline MGSC 403 E- Commerce (New) & $\mathbf{3}$ \\
\hline MGSC 410 Total Quality Management (New) & $\mathbf{3}$ \\
\hline MGSC 440 Modeling and Simulation of Supply Chain (New) & 3 \\
\hline Business Elective* (any existing 400 level business course) & \\
\hline * Internship programs in SCM area can be taken for course credit. & \\
\hline
\end{tabular}




\section{Description Of Courses In The Major Area}

\section{MGSC 331 Business Statistics II}

Special topics in Statistics including regression, correlation, analysis of variance, time series, and non-parametric statistics as related to statistical decision theory applied to business problems. Pre-requisites: MGSC 239

MGSC 303 Operations Management II

Analysis and modeling of contemporary problems in the OM area. Topics include introduction to supply chain, inventory control and aggregate planning, MRP \& CRP, waiting line models, just-in-time manufacturing, and productivity. Pre-requisites: MGSC 302

MGSC 304 Information Technology

Development of software skills and an appreciation of the role of information technology in modern organizations. Pre-requisites: CS 116(Existing) and junior standing.

MGSC 307 Purchasing Management

Provides a broad exposure to the purchasing function in modern organizations. Topics include purchasing processes, vendor assessment, contract negotiations, global operations, and ethical issues. Pre-requisite: MGSC 303

MGSC 309 Logistics Management

Quantitative approaches to transportation management at national and global levels for inbound materials and supplies, and outbound for finished products to minimize costs and discussion of related qualitative issues. Prerequisite: MGSC 303, MGMT 402

MGMT 402 International Management

Management processes as they apply within different cultural environments with emphasis on contrasts among values, beliefs, perceptions, attitudes, and behavior, including consideration of their effects on businesses. Pre-requisite: MGMT 300 or consent of instructor.

MKTG 430 Marketing Research

Role of information in marketing decision making with emphasis on the application of research concepts and methodologies to marketing problems. Pre-requisite: MGSC 239, MKTG 306

\section{MGSC 403 E-Commerce}

Students are exposed to national and global scale internet based transactions between businesses and customers with the help of an instructor selected commercial software.

Pre-requisite: MGSC 301, MGMT 402

MGSC 410 Total Quality Management

Students are exposed to a number of statistical quality control models with business applications and the role of other corporate functional areas outside of production function in contributing to final product quality. Prerequisite: MGSC 331, MGSC 403 
This course enables students to understand the complex interactions between stages in the supply chain and how changes at one or more stages affect the supply chain performance.

An instructor selected software will be used in the course.

Pre-requisite: MGSC 309, MGSC 410, MKTG 430

\section{COMMENTS}

The above curriculum provides a balanced exposure to the topical areas of supply chain management and provides students with the skills required to perform effectively in the SCM area. The program requires the creation of 5 new courses only and incorporates the existing courses wherever possible. Typically the program will require 3 terminally and academically qualified faculty members and the indicated software and additional periodicals/journals in the SCM area.

\section{REFERENCES}

1. Copra and Meindl, Supply Chain Management, Second Edition, Pearson/Prentice Hall year 2004

2. Catalogue description of curriculum for a major in Supply Chain Management at the undergraduate level, Michigan University, East Lansing, MI

3. Van Der Zee, D. J. and Van Der Vorst, J., G. A. J. A Modeling Framework for Supply Chain Simulation: Opportunities for Improved Decision Making Decision Sciences, Vol.36, No. 1, Feb. 2005

4. Vakharia, Asoo J,:e-Business and Supply Chain Management, Decision Sciences, Vol. 33 No.4, Fall 2002.

5. Hausman, Warren, Founder of Supply Chain Seminars and Professor of Management Science and Engineering, Stanford University, from current website advertisement.

\section{NOTES}

